\title{
Rare but lethal short QT understanding of the disease
}

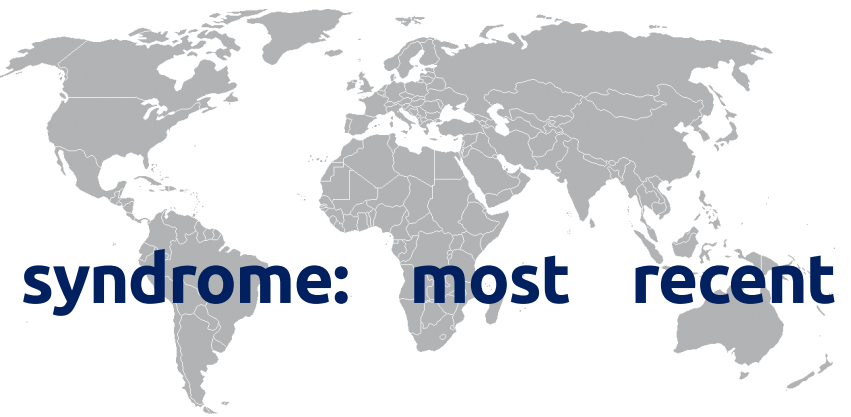

\section{Síndrome de QT corto, inusual con potential letal: Revisión reciente de esta enfermedad}

\author{
Mustafa Al Qaysi ${ }^{1}$, Juan Simon Rico-Mesa ${ }^{1,2^{\star}}$, William Sovic ${ }^{1}$, Manuel Endo-Carvajal ${ }^{1}$, Auroa Badin ${ }^{1}$
}

\begin{abstract}
Short QT syndrome (SQTS) is a rare genetic channelopathy that affects the repolarization of cardiac cells and is associated with cardiac arrhythmia and sudden cardiac death (SCD). "Abbreviated repolarization" is the hallmark of the disease, which is secondary to genetic defects; mutations in several genes that encode different cardiac ion channels have been identified in individuals with the disease. Presentations of the disease include syncope, atrial or ventricular arrhythmia and SCD. SQTS is diagnosed with a corrected-QT (QTc) interval of $<340$ milliseconds (ms) or a QTc of 340-360 ms and either personal or family history of SCD, family history of SQTS or an identified genetic mutation. Implantable cardioverter-defibrillator (ICD) is the main treatment used in the secondary prevention of SCD in patients with the disease who have experienced previous major arrhythmic events. Pharmacological treatment with quinidine is used as an adjuvant therapy to ICD in the setting of recurrent shocks or as an alternative treatment when ICD is not feasible. The goal of this review article is to describe this rare and under-studied condition, highlight steps to diagnosis and describe treatment modalities, particularly in South America where there is a lack of studies and understanding of this disease.
\end{abstract}

Keywords: genetic, electrocardiogram, sudden cardiac death, ventricular fibrillation, short QT syndrome

\section{RESUMEN}

El síndrome de QT corto es una canalopatía genética que afecta la repolarización de las células cardiacas, asociado a arritmias cardíacas y a muerte súbita cardíaca. El concepto de "repolarización abreviada" es el mecanismo fisiopatológico de esta enfermedad, secundario a defectos genéticos en la codificación de diferentes canales iónicos cardiacos. Esta enfermedad se presenta usualmente con síncope, arritmias auriculares y ventriculares, y muerte súbita cardíaca. El síndrome de QT corto es diagnosticado al hallar un intervalo QT corregido (QTc) <340 milisegundos (ms) o un QTc de 340360 ms con uno de los siguientes requisitos: historia personal o familiar de muerte súbita cardíaca, historia familiar de síndrome de QT corto o mutaciones genéticas previamente identificadas. El desfibrilador cardíaco implantable es el principal tratamiento utilizado para la prevención secundaria de muerte súbita cardíaca en pacientes diagnosticados con dicho síndrome quienes hayan experimentado episodios de arritmia previos. El tratamiento farmacológico con Quinidina se ha utilizado como terapia adjuvante al desfibrilador cardíaco implantable en el contexo de descargas recurrentes o como terapia alternativa en casos en los que el desfibrilador cardíaco implantable no pueda ser implantado o suponga altos riesgos para el paciente. El objetivo de este artículo de revision consiste en describir esta infrequente enfermedad, resaltar los pasos para llegar al diagnóstico y describir las modalidades terapéuticas, particularmente en Suramérica, en donde existen vacíos en el conocimiento en general de esta enfermedad.

Palabras clave: genética, electrocardiograma, muerte súbita cardíaca, fibrilación ventricular, síndrome de QT corto

\section{INTRODUCTION}

Short QT Syndrome (SQTS) is a rare inherited condition that has only relatively newly been described; it is caused by a defect in cell membrane ion channels affecting the action potential of cardiac myocytes, and is associated with atrial and ventricular arrhythmias (1). To date, several different genes have been linked to SQTS. Prior the syndrome ever being initially characterized, it was discovered using longitudinal data that a corrected QT (QTc) <400 ms was associated with a 2.4-fold increase in SCD (2). It was only in the year 2000 that short QTc interval was postulated as an inherited arrhythmogenic syndrome after the case of a young female with atrial fibrillation, a QT of $280 \mathrm{~ms}$, and a mother and

\footnotetext{
Department of Medicine, UT Health San Antonio, San Antonio, Texas, United States.

2 Department of Cardiovascular Diseases, Division of Echocardiography, Mayo Clinic, Rochester, Minnesota, United States.
}

Correspondence: Juan Simon Rico-Mesa

Department of Medicine, UT Health San Antonio, San Antonio, Texas, United States Department of Cardiovascular Diseases, Division of Echocardiography, Mayo Clinic, Rochester, Minnesota, United States

(c) 2019 by the authors; licensee Modestum Ltd., UK. This article is an open access article distributed under the terms and conditions of the Creative Commons Attribution License (http://creativecommons.org/licenses/by/4.0/). 
Action potential of cardiac muscles
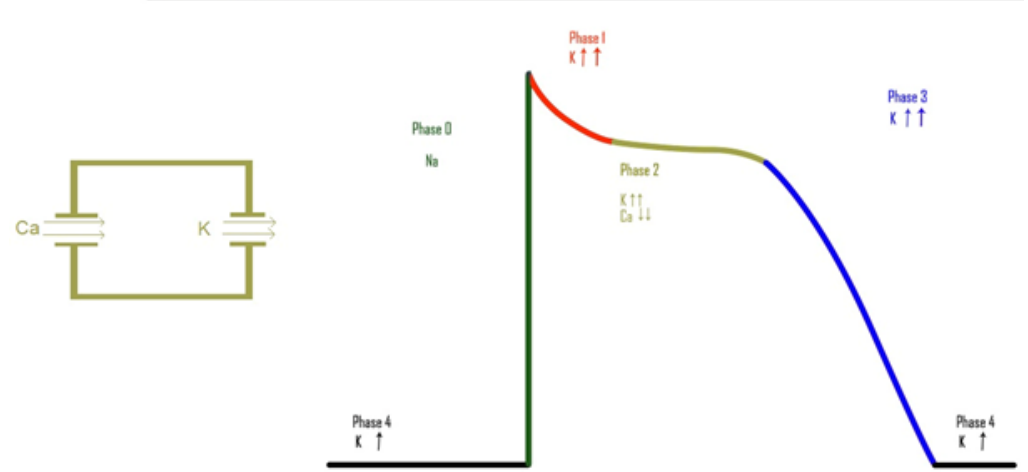

Figure 1: Normal Action potential

Source: Elaborated by the authors

brother who likewise had shortened QT intervals was described (3). Since then, over a 100 cases of SQTS have been reported and awareness of the disease has risen. Despite this rise in awareness, our understanding of this rare syndrome remains limited.

\section{EPIDEMIOLOGY}

Rare diseases in which death can be the initial presentation, such as SQTS, make the true prevalence of these diseases hard to determine. The prevalence of a short QTc interval (not necessarily short QT syndrome) also varies depending on the population and the defining cutoff, further complicating any determination of the prevalence of the disease. Most large cohorts use a QTc cutoff of less than $360 \mathrm{~ms}$. In the United States, a QTc of $<360 \mathrm{~ms}$ was found in $2 \%$ of 46,129 healthy subjects (4). A retrospective study of 486,014 primary care based patients in Brazil found a QTc of $<370 \mathrm{~ms}$ in $2 \%$ of the population (5). Where as in Japan a QTc interval $\leq 357 \mathrm{~ms}$ in males and $\leq 364 \mathrm{~ms}$ in females was found in $0.37 \%$ of a large cohort (6). A Swiss cohort of 41,767 male army individuals reported a 1\% prevalence of short QTc intervals $(<347 \mathrm{~ms})(7)$.

\section{PATHOPHYSIOLOGY}

The "electrical" activity of cardiac myocytes is mainly generated by ion movements through ion channels, creating the cardiac action potential (AP) (8). The depolarizing current starts after the opening of fast sodium channels $\left(I_{\text {Na }}\right)$ which allow rapid influx of sodium into the cell (8). Repolarizing current is generated by potassium efflux from the cell through potassium channels $\left(I_{K_{r},} I_{K_{s}} I_{k 1}\right)(8-10)$. Repolarization plateaus temporarily as a result of calcium ion influx $(8,9)$. (Figure 1). The QT interval is a representation of the length of a whole AP cycle. A disturbance in the aforementioned ion channels will affect the length of AP and in turn the QT interval $(9,10)$. Therefore, defects that decrease the function of sodium or calcium channels and/or increase the function of potassium channels would lead to shortening of the QT interval. Several genotypes of SQTS have been described and linked to specific ion channel defects (10); those are summarized in Table 1. 
Table 1: Genotypes identified for SQTS with their corresponding ion channelopathy

\begin{tabular}{|c|c|c|c|c|c|}
\hline $\begin{array}{c}\text { SQT } \\
\text { variant }\end{array}$ & Gene & Channel & Amino acid change & Original study & $\begin{array}{c}\text { Length QTc (QT) } \\
\text { interval }\end{array}$ \\
\hline \multirow{6}{*}{ SQT1 } & \multirow{6}{*}{$\mathrm{KCNH} 2$} & \multirow{6}{*}{$\mathrm{I}_{\mathrm{kr}}$} & N588K & Brugada et al. & $\leq 300$ \\
\hline & & & T618I & Sun et al. & $316 \pm 9$ \\
\hline & & & E50D & Redpath et al. & $366-381$ \\
\hline & & & I560T & Harrell et al. & 319 \\
\hline & & & $\mathrm{R} 1135 \mathrm{H}$ & Itoh et al. & 329 \\
\hline & & & S631A & Akdis et al. & $<320$ \\
\hline \multirow{6}{*}{ SQT2 } & \multirow{6}{*}{ KCNQ1 } & \multirow{6}{*}{$\mathrm{I}_{\mathrm{Ks}}$} & V307L & Bellocq et al. & 302 \\
\hline & & & V141M & Hong et al. & 294 \\
\hline & & & I274V & Rhodes et al. & - \\
\hline & & & F279I & Moreno et al. & 356 \\
\hline & & & $\mathrm{R} 259 \mathrm{H}$ & Mazzanti et al. & 316 \\
\hline & & & A287T & Rothenberg et al. & 333 \\
\hline \multirow{4}{*}{ SQT3 } & \multirow{4}{*}{ KCNJ2 } & \multirow{4}{*}{ Ik1 } & D172N & Priori et al. & $315-330$ \\
\hline & & & M301K & Hattori et al. & 194 \\
\hline & & & E299V & Deo et al. & 200 \\
\hline & & & K346T & Ambrosini et al. & 331 \\
\hline \multirow{3}{*}{ SQT4 } & \multirow{3}{*}{ CACNA1C } & \multirow{3}{*}{ Ica } & A39V & Antzelevitch et al. & 360 \\
\hline & & & G490R & Antzelevitch et al. & $346-373$ \\
\hline & & & R1977Q & Mazzanti et al. & $346-360$ \\
\hline SQT5 & CACNB2b & $\mathrm{I}_{\mathrm{Ca}}$ & S481L & Antzelevitch et al. & $331-370$ \\
\hline SQT6 & CACNA2D1 & $\mathrm{I}_{\mathrm{Ca}}$ & S755T & Templin et al. & 330 \\
\hline SQT7 & SCN5A & $\mathrm{I}_{\mathrm{Na}}$ & $\mathrm{R} 689 \mathrm{H}$ & Hong et al. & 320 \\
\hline SQT8 & SLC4A3 & $\begin{array}{c}\text { Anion exchanger } \mathrm{AE3}(\mathrm{Cl}, \mathrm{HCO}- \\
\text { exchanger })\end{array}$ & $\mathrm{R} 370 \mathrm{H}$ & Thorsen et al. & $322-358$ \\
\hline
\end{tabular}

Source: Adapted from Priori et al. (2005) (10), Brugada et al. (2004) (11), Sun et al. (2011) (12), Redpath et al. (2009) (13), Harrell et al. (2015) (14), Itoh et al. (2009) (15), Akdis et al. (2018) (16), Bellocq et al. (2004) (17), Hong et al. (2005) (18), Rhodes et al. (2008) (19), Moreno et al. (2015) (20), Mazzanti et al.(2014) (21), Rothenberg et al. (2016) (22), Hattori et al. (2012) (23), Deo et al. (2013) (24), Ambrosini et al. (2014) (25), Antzelevitch et al. (2007) (26), Templin et al. (2011) (27), Hong et al. (2012) (28), Thorsen et al. (2017) (29)

Action potential of cardiac muscles in SQTS

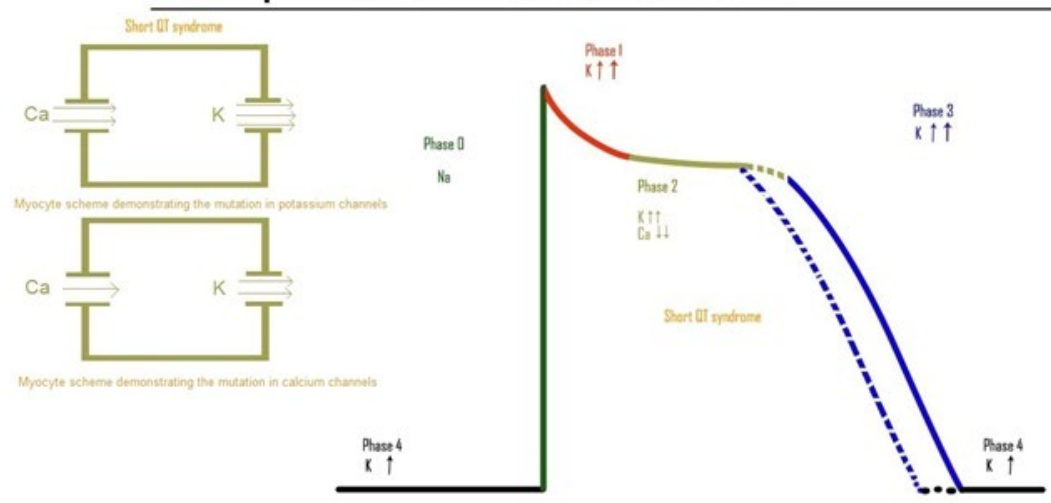

Figure 2: Action potential in SQTS

SQTS = Short QT Syndrome.

Source: Elaborated by the authors

Gain of function mutations of genes KCNH2, KCNQ1 and KCNJ2 increase the efflux of potassium $(10,11,17)$. On the other hand, loss of function mutations in CACNB2b, CACNA1C and CACNA2D1 decrease the influx of calcium into the cell $(26,27)$. These mutations and their effects on cellular ion movements decrease the duration of the AP by enhancing repolarization, as evidenced by the ECG finding of short J-point to T-peak interval noticed in some patients with SQTS [Figure 2] $(26,27,30)$. Loss of function mutation in SCN5A causes a decrease in sodium influx thereby shortening the QTC (28). Less than $25 \%$ of SQTS cases are explained by cation channel mutations. Other classes of genes, therefore, are likely to be linked with the development of SQTS.(31). However, few other genes mutations have been identified in SQTS that don't directly affect the function of ion channels. Roussel et al. described three patients with SLC22A5 gene mutation, resulting in carnitine deficiency and SQTS, QTc was significantly shortened (282-340) in these individuals and was 
corrected with carnitine supplementation. Carnitine deficiency in these individuals is thought to affect the rapid potassium channels (IKr) $(30,32)$. Recently, a "loss of function" mutation in the SLC4A3 gene, which encodes the cardiac chloride-bicarbonate exchanger AE3, was reported by Thorsen et al. to be associated with SQTS. This mutation was associated with an increase in intracellular $\mathrm{pH}$, causing a potential shortening in QTc (29).

\section{DIAGNOSIS}

In 2013, the Heart Rhythm Society/European Heart Rhythm Association/Asian Pacific Heart Rhythm Society expert consensus statement defined a standalone QTc of $<330 \mathrm{~ms}$ as sufficient to make the diagnosis of SQTS (33). However, since then, Mazzanti et al. (2014) described 73 patients with SQTS including 21 patients with a QTC > 330, supporting a previously published study by Giustetto on the presence of the disease in patients with a higher QTc $(21,34)$. The European Society of Cardiology in 2015 suggested a QTc of $<340$ as diagnostic of SQTS (Class of recommendation I, Level of evidence C) (35). The diagnosis of SQTS in patients with QTc 340-360 ms is suggested by short QTc plus one of the following (Class of recommendation Ila, Level of evidence C) (35):

- A confirmed pathogenic mutation

- A family history of SQTS

- A family history of sudden death at age $<40$ years

- Survival from a VT/VF episode in the absence of heart disease

Another diagnostic criterion proposed by Giustetto et al. (2015) for patients with a QTc 340-360 ms is poor adaptation (poor expected shortening) of the QT interval to an increase in heart rate. In Giustetto et al. study, 21 individuals with SQTS were studied and noticed to have decreased QTc adaptation in response to exercise ( $\triangle$ QTc at rest-QT at peak was $48 \pm 14 \mathrm{~ms}$ in SQTS patients versus $120 \pm 20 \mathrm{~ms}$ in the normal control group) (36). This study was limited by fact that the control group was composed of healthy individuals with normal QTc rather than non-SQTS individuals with short QTC.

\section{ARRHYTHMOGENESIS IN SQTS}

Net inward depolarization currents, outward repolarization currents or a combination of both explain the shortening of the action potential leading to SQTS. The most common depolarization channels involved are the $I_{\mathrm{Na}}$ and $I_{\mathrm{Ca}}$. For repolarization channels, $I_{\mathrm{to}}, I_{\mathrm{K} 1}, I_{\mathrm{K}-\mathrm{ATP}} I_{\mathrm{ACh}}, I_{\mathrm{Kr}}$ or $I_{\mathrm{Ks}}$ represent the most commonly involved in SQTS. An increase in the transmural dispersion of repolarization caused by defective ion channels has been described as a cause for cardiac circuit reentry and arrhythmia, creating a unidirectional block and also shortening the action potential. This effect was first described in experimental studies involving canine models, where specific $\mathrm{I}_{\mathrm{kr}}$ agonists were administered causing a shortening of the SQTS and leading to an increase in the transmural dispersion of repolarization (37). Factors such as the shortening of wave length can also explain the maintenance of the refractory period, as described by Patel, Yan and Antzelevitch (2010). Mutations involving a loss of function in inward $I_{\text {ca-L }}$ channels and gain of function in outward $\mathrm{K}$ channels may shorten the QT interval as well (37).

\section{SCREENING AND RISK STRATIFICATION}

Identifying individuals with SQTS is essential for implementing adequate and appropriate treatment and prevention strategies. A proposed scoring system developed by Gollob, Redpath and Roberts (2011) is helpful for stratifying highrisk individuals (38). This system, however, remains difficult to validate due to the small number of people with SQTS but is a helpful tool in identifying high-risk patients. This scoring system was modified by Villafane et al. (2013) and validated in 25 patients (Table 2) (39).

ECG screening is recommended for newborns with a family history of SQTS (40). Genetic testing is only recommended for those subjects with a high suspicion of SQTS (1). Invasive strategies such as routine electrophysiological study are not recommended since they have not showed a clear benefit in both diagnostic yield and in risk stratification (1). 
Table 2: Modified Gollob's score for identifying patients with high risk to develop symptoms

\begin{tabular}{ll}
\hline Criteria & Points \\
\hline QTc, milliseconds & 1 \\
\hline$<370$ & 2 \\
\hline$<350$ & 3 \\
\hline$<330$ & 1 \\
\hline J-point to T-peak interval <120 milliseconds & 2 \\
\hline Family history* & 1 \\
\hline First- or second-degree relative with high probability of SQTS & 1 \\
\hline Sirst- or second-degree relative with autopsy-negative sudden cardiac death & \\
\hline Genotype* & \\
\hline Genotype positive & \\
\hline Mutation of undetermined significance in a culprit gene & 1 \\
\hline
\end{tabular}

Individuals with a score of 5 or more were symptomatic.

Source: Adapted from Villafane et al. (2013) (39)

\section{MANAGEMENT}

Management of SQTS is based on expert consensus recommendations due to the lack of clinical trials. Current guidelines do not support primary prevention for patients without a previous episode of SCD. However frequent followup and referral to an electrophysiology specialist may be recommended in those asymptomatic individuals (39). In patients with SQTS who survived cardiac arrest, ICD placement is always recommended for secondary prevention of SCD (Class I recommendation according to AHA/ACC/HRS, ESC, and HRS/EHRA/APHRS guidelines) $(1,33,35)$. These patients have a high incidence of recurrence of SCD. In a small study published by Giusteto et al. (2011) and Villafane et al. (2018), $18 \%$ of patients with SQTS and ICD implantation experienced appropriate ICD treatment during short term follow-up $(34,39,41)$. However, patients with SQTS are prone to inappropriate shocks with the conventional programming of the ICD due to double sensing of the QRS complex and the short, sharp and high amplitude T-wave. Revision of programming with reduced sensitivity levels and decay delays effectively limited T wave oversensing $(42,43)$. Medical treatment is used as an adjuvant therapy to ICD for patients with recurrent shocks, those who refuse ICD placement or patients with contraindications to ICD. Quinidine has been described as the optimal medical treatment for SQTS. In fact, several small studies showed normalization or prolongation of the QTc interval with quinidine $(1,34,44-46)$. In addition, it has been shown to decrease the frequency of shocks in those with ICDs $(1,34,45,46)$. Isoproterenol infusion can be effective in terminating electrical storm with refractory ventricular arrhythmia and restoring normal rhythm (Class $I$ recommendation for this according to AHA/ACC/HRS guidelines) (1). In a small cohort of patients evaluated by Hong et al. (2005) (47), propafenone was found to be effective in treating atrial fibrillation in patients with SQTS (10). Multiple other medications (amiodarone, ibutilide, sotalol, flecainide, and metoprolol) have been described in individual case reports or in vitro studies but have not been replicated $(12,31,34,48-50)$.

\section{CONCLUSIONS}

Short QT syndrome is a rare genetic channelopathy that can manifest at any age. Affected individuals might be asymptomatic or might suffer from syncope or atrial or ventricular arrhythmias. Several genetic mutations have been identified and linked to SQTS. Diagnostic criteria for the disease have evolved over the years since the syndrome was discovered as new studies and research continue to emerge. Diagnosis is made in an asymptomatic individual with a QTc of $<340$ ms or an individual with a QTc of 340-360 and a positive gene mutation or a family history of SCD or SQTS or a personal history of SCD. ICD implantation and/or quinidine are recommended for secondary prevention of SCD. Primary prevention of SCD is controversial. Our understanding of the disease is very limited and mainly based on case series and small studies primarily done in Europe and the USA; very few cases have been reported in Latin American populations. Increased awareness of the syndrome is crucial to allow for the identification of a larger cohort needed for the conduction of bigger studies to increase our understanding of this deadly syndrome; this is especially true in Latin America where there is a lack of information regarding the diagnosis and treatment of this severe condition. 


\section{REFERENCES}

1. Al-Khatib SM, Stevenson WG, Ackerman MJ, et al. 2017 AHA/ACC/HRS guideline for management of patients with ventricular arrhythmias and the prevention of sudden cardiac death: executive summary: a report of the American College of Cardiology/American Heart Association Task Force on Clinical Practice Guidelines and the Heart Rhythm Society. J Am Coll Cardiol. 2018;72(14):1677-749. https://doi.org/10.1016/j.jacc.2017.10.053 PMid:29097294

2. Algra A, Tijssen JG, Roelandt JR, Pool J, Lubsen J. QT interval variables from 24 hour electrocardiography and the two year risk of sudden death. Heart. 1993;70(1):43-8. https://doi.org/10.1136/hrt.70.1.43

3. Gussak I, Brugada P, Brugada J, et al. Idiopathic short QT interval: a new clinical syndrome? Cardiology. 2000;94(2):99-102. https://doi.org/10.1159/000047299 PMid:11173780

4. Mason JW, Ramseth DJ, Chanter DO, Moon TE, Goodman DB, Mendzelevski B. Electrocardiographic reference ranges derived from 79,743 ambulatory subjects. J Electrocardiol. 2007;40(3):228-34.e8. https://doi.org/10.1016/j.jelectrocard.2006.09.003 PMid:17276451

5. Palhares DMF, Marcolino MS, Santos TMM, et al. Normal limits of the electrocardiogram derived from a large database of Brazilian primary care patients. BMC Cardiovasc Disord. 2017;17(1):152. https://doi.org/10.1186/s12872-017-0572-8 PMid:28610624 PMCid:PMC5470250

6. Miyamoto A, Hayashi $\mathrm{H}$, Yoshino $\mathrm{T}$, et al. Clinical and electrocardiographic characteristics of patients with short QT interval in a large hospital-based population. Heart Rhythm. 2012;9(1):66-74. https://doi.org/10.1016/j.hrthm.2011.08.016 PMid:21855519

7. Kobza R, Roos M, Niggli B, et al. Prevalence of long and short QT in a young population of 41,767 predominantly male Swiss conscripts. Heart Rhythm. 2009;6(5):652-7. https://doi.org/10.1016/j.hrthm.2009.01.009 PMid:19303371

8. Rudy Y. Molecular basis of cardiac action potential repolarization. Ann N Y Acad Sci. 2008;1123(1):113-8. https://doi.org/10.1196/annals.1420.013 PMid:18375583

9. Brugada R, Hong K, Cordeiro JM, Dumaine R. Short QT syndrome. CMAJ Can Med Assoc J. 2005;173(11):134954. https://doi.org/10.1503/cmaj.050596 PMid:16301704 PMCid:PMC1283503

10. Priori SG, Pandit SV, Rivolta I, et al. A novel form of short QT syndrome (SQT3) is caused by a mutation in the KCNJ2 gene. Circ Res. 2005;96(7):800-7. https://doi.org/10.1161/01.RES.0000162101.76263.8c PMid:15761194

11. Brugada $R$, Hong $K$, Dumaine $R$, et al. Sudden death associated with short-QT syndrome linked to mutations in HERG. Circulation. 2004;109(1):30-5. https://doi.org/10.1161/01.CIR.0000109482.92774.3A PMid:14676148

12. Sun $Y$, Quan $X-Q$, Fromme $S$, et al. A novel mutation in the $K C N H 2$ gene associated with short QT syndrome. J Mol Cell Cardiol. 2011;50(3):433-41. https://doi.org/10.1016/j.yjmcc.2010.11.017 PMid:21130771

13. Redpath CJ, Green MS, Birnie DH, Gollob MH. Rapid genetic testing facilitating the diagnosis of short QT syndrome. Can J Cardiol. 2009;25(4):e133-5. https://doi.org/10.1016/S0828-282X(09)70077-7

14. Harrell DT, Ashihara T, Ishikawa T, et al. Genotype-dependent differences in age of manifestation and arrhythmia complications in short QT syndrome. Int J Cardiol. 2015;190:393-402. https://doi.org/10.1016/j.ijcard.2015.04.090 PMid:25974115

15. Itoh H, Sakaguchi T, Ashihara T, et al. A novel KCNH2 mutation as a modifier for short QT interval. Int J Cardiol. 2009;137(1):83-5. https://doi.org/10.1016/j.ijcard.2008.05.050 PMid:18692916

16. Akdis D, Saguner AM, Medeiros-Domingo A, et al. Multiple clinical profiles of families with the short QT syndrome. EP Eur. 2018;20(FI1):f113-21. https://doi.org/10.1093/europace/eux186 PMid:29016797

17. Bellocq $C$, van Ginneken ACG, Bezzina CR, et al. Mutation in the KCNQ1 gene leading to the short QT-interval syndrome. Circulation. 2004;109(20):2394-7. https://doi.org/10.1161/01.CIR.0000130409.72142.FE PMid:15159330

18. Hong K, Piper D, Diazvaldecantos A, et al. De novo KCNQ1 mutation responsible for atrial fibrillation and short QT syndrome in utero. Cardiovasc Res. 2005;68(3):433-40. https://doi.org/10.1016/j.cardiores.2005.06.023 PMid:16109388

19. Rhodes $\mathrm{TE}$, Abraham RL, Welch $\mathrm{RC}$, et al. Cardiac potassium channel dysfunction in sudden infant death syndrome. J Mol Cell Cardiol. 2008;44(3):571-81. https://doi.org/10.1016/j.yjmcc.2007.11.015 PMid:18222468 PMCid:PMC2386856 
20. Moreno C, Oliveras A, de la Cruz A, et al. A new KCNQ1 mutation at the S5 segment that impairs its association with KCNE1 is responsible for short QT syndrome. Cardiovasc Res. 2015;107(4):613-23. https://doi.org/10.1093/cvr/cvv196 PMid:26168993

21. Mazzanti A, Kanthan A, Monteforte N, et al. Novel insight into the natural history of short QT syndrome. J Am Coll Cardiol. 2014;63(13):1300-8. https://doi.org/10.1016/j.jacc.2013.09.078 PMid:24291113 PMCid:PMC3988978

22. Rothenberg I, Piccini I, Wrobel E, et al. Structural interplay of KV7.1 and KCNE1 is essential for normal repolarization and is compromised in short QT syndrome 2 (KV7.1-A287T). Hear Case Rep. 2016;2(6):521-9. https://doi.org/10.1016/j.hrcr.2016.08.015 PMid:28491751 PMCid:PMC5420010

23. Hattori T, Makiyama T, Akao M, et al. A novel gain-of-function KCNJ2 mutation associated with short-QT syndrome impairs inward rectification of Kir2.1 currents. Cardiovasc Res. 2012;93(4):666-73. https://doi.org/10.1093/cvr/cvr329 PMid:22155372

24. Deo M, Ruan Y, Pandit SV, et al. KCNJ2 mutation in short QT syndrome 3 results in atrial fibrillation and ventricular proarrhythmia. Proc Natl Acad Sci. 2013;110(11):4291-6. https://doi.org/10.1073/pnas.1218154110 PMid:23440193 PMCid:PMC3600465

25. Ambrosini E, Sicca F, Brignone MS, et al. Genetically induced dysfunctions of Kir2.1 channels: implications for short QT3 syndrome and autism-epilepsy phenotype. Hum Mol Genet. 2014;23(18):4875-86. https://doi.org/10.1093/hmg/ddu201 PMid:24794859 PMCid:PMC4140467

26. Antzelevitch C, Pollevick GD, Cordeiro JM, et al. Loss-of-function mutations in the cardiac calcium channel underlie a new clinical entity characterized by ST-segment elevation, short QT intervals, and sudden cardiac death. Circulation. 2007;115(4):442-9. https://doi.org/10.1161/CIRCULATIONAHA.106.668392 PMid:17224476 PMCid:PMC1952683

27. Templin C, Ghadri J-R, Rougier J-S, et al. Identification of a novel loss-of-function calcium channel gene mutation in short QT syndrome (SQTS6). Eur Heart J. 2011;32(9):1077-88. https://doi.org/10.1093/eurheartj/ehr076 PMid:21383000 PMCid:PMC3086900

28. Hong K, Hu J, Yu J, Brugada R. Concomitant Brugada-like and short QT electrocardiogram linked to SCN5A mutation. Eur J Hum Genet. 2012;20(11):1189-92. https://doi.org/10.1038/ejhg.2012.63 PMid:22490985 PMCid:PMC3476719

29. Thorsen K, Dam VS, Kjaer-Sorensen K, et al. Loss-of-activity-mutation in the cardiac chloride-bicarbonate exchanger AE3 causes short QT syndrome. Nat Commun. 2017;8(1):1696. https://doi.org/10.1038/s41467-01701630-0 PMid:29167417 PMCid:PMC5700076

30. Roussel J, Labarthe F, Thireau J, et al. Carnitine deficiency induces a short QT syndrome. Heart Rhythm. 2016;13(1):165-74. https://doi.org/10.1016/j.hrthm.2015.07.027 PMid:26190315

31. Bjerregaard P. Diagnosis and management of short QT syndrome. Heart Rhythm. 2018;15(8):1261-7. https://doi.org/10.1016/j.hrthm.2018.02.034 PMid:29501667

32. Ferro F, Ouillé $A$, Tran T-A, et al. Long-chain acylcarnitines regulate the hERG channel. PLoS ONE. 2012;7(7):e41686. https://doi.org/10.1371/journal.pone.0041686 PMid:22848566 PMCid:PMC3404973

33. Priori SG, Wilde AA, Horie $M$, et al. HRS/EHRA/APHRS expert consensus statement on the diagnosis and management of patients with inherited primary arrhythmia syndromes: document endorsed by HRS, EHRA, and APHRS in May 2013 and by ACCF, AHA, PACES, and AEPC in June 2013. Heart Rhythm. 2013;10(12):1932-63. https://doi.org/10.1016/j.hrthm.2013.05.014 PMid:24011539

34. Giustetto C, Schimpf R, Mazzanti A, et al. Long-term follow-up of patients with short QT syndrome. J Am Coll Cardiol. 2011;58(6):587-95. https://doi.org/10.1016/j.jacc.2011.03.038 PMid:21798421

35. Priori SG, Blomström-Lundqvist C, Mazzanti A, et al. 2015 ESC Guidelines for the management of patients with ventricular arrhythmias and the prevention of sudden cardiac death: The task force for the management of patients with ventricular arrhythmias and the prevention of sudden cardiac death of the European Society of Cardiology (ESC) endorsed by: Association for European Paediatric and Congenital Cardiology (AEPC). Eur Heart J. 2015;36(41):2793-867. https://doi.org/10.1093/eurheartj/ehv316 PMid:26320108

36. Giustetto C, Scrocco C, Schimpf R, et al. Usefulness of exercise test in the diagnosis of short QT syndrome. Europace. 2015;17(4):628-34. https://doi.org/10.1093/europace/euu351 PMid:25833882

37. Patel C, Yan G-X, Antzelevitch C. Short QT syndrome: from bench to bedside. Circ Arrhythm Electrophysiol. 2010;3(4):401-8. https://doi.org/10.1161/CIRCEP.109.921056 PMid:20716721 PMCid:PMC2933105 
38. Gollob MH, Redpath CJ, Roberts JD. The short QT syndrome. J Am Coll Cardiol. 2011;57(7):802-12. https://doi.org/10.1016/j.jacc.2010.09.048 PMid:21310316

39. Villafañe J, Atallah J, Gollob $\mathrm{MH}$, et al. Long-term follow-up of a pediatric cohort with short QT syndrome. J Am Coll Cardiol. 2013;61(11):1183-91. https://doi.org/10.1016/j.jacc.2012.12.025 PMid:23375927

40. Pereira R, Campuzano O, Sarquella-Brugada G, et al. Short QT syndrome in pediatrics. Clin Res Cardiol. 2017;106(6):393-400. https://doi.org/10.1007/s00392-017-1094-1 PMid:28303324

41. Giustetto C, Di Monte F, Wolpert C, et al. Short QT syndrome: clinical findings and diagnostic-therapeutic implications. Eur Heart J. 2006;27(20):2440-7. https://doi.org/10.1093/eurheartj/ehl185 PMid:16926178

42. Anttonen O, Junttila J, Giustetto $C$, et al. T-wave morphology in short QT syndrome. Ann Noninvasive Electrocardiol. 2009;14(3):262-7. https://doi.org/10.1111/j.1542-474X.2009.00308.x PMid:19614638

43. Schimpf R, Wolpert C, Bianchi F, et al. Congenital short QT syndrome and implantable cardioverter defibrillator treatment: inherent risk for inappropriate shock delivery. J Cardiovasc Electrophysiol. 2003;14(12):1273-7. https://doi.org/10.1046/j.1540-8167.2003.03278.x PMid:14678099

44. Bjerregaard P, Gussak I. Short QT syndrome: mechanisms, diagnosis and treatment. Nat Clin Pract CardiovasC Med. 2005;2(2):84-7. https://doi.org/10.1038/ncpcardio0097 PMid:16265378

45. Gaita F, Giustetto C, Bianchi F, et al. Short QT syndrome: a familial cause of sudden death. Circulation. 2003;108(8):965-70. https://doi.org/10.1161/01.CIR.0000085071.28695.C4 PMid:12925462

46. Mazzanti A, Maragna R, Vacanti G, et al. Hydroquinidine prevents life-threatening arrhythmic events in patients with short QT syndrome. J Am Coll Cardiol. 2017;70(24):3010-5. https://doi.org/10.1016/j.jacc.2017.10.025 PMid:29241489

47. Hong K, Bjerregaard P, Gussak I, Brugada R. Short QT syndrome and atrial fibrillation caused by mutation in KCNH2. J Cardiovasc Electrophysiol. 2005;16(4):394-6. https://doi.org/10.1046/j.1540-8167.2005.40621.x PMid:15828882

48. Lu LX, Zhou W, Zhang X, Cao Q, Yu K, Zhu C. Short QT syndrome: A case report and review of literature. Resuscitation. 2006;71(1):115-21. https://doi.org/10.1016/j.resuscitation.2006.03.011 PMid:16942825

49. Giustetto C, Scrocco C, Giachino D, Rapezzi C, Mognetti B, Gaita F. The lack of effect of sotalol in short QT syndrome patients carrying the T618I mutation in the KCNH2 gene. Hear Case Rep. 2015;1(5):373-8. https://doi.org/10.1016/j.hrcr.2015.07.001 PMid:28491588 PMCid:PMC5419677

50. Hancox JC, Whittaker DG, Du C, Stuart AG, Zhang H. Emerging therapeutic targets in the short QT syndrome. Expert Opin Ther Targets. 2018;22(5):439-51. https://doi.org/10.1080/14728222.2018.1470621 PMid:29697308

$\diamond \diamond \diamond \diamond \diamond \diamond \diamond$

http://www.ejgm.co.uk 